\title{
The Development of an Assessment for Learning Model for Elementary Classroom
}

\author{
Satayu Chueachot ${ }^{1}$, Boonchom Srisa-ard ${ }^{1} \&$ Yannapat Srihamongkol $^{1}$ \\ ${ }^{1}$ Faculty of Education, Mahasarakham University, Thailand \\ Correspondence: Satayu Chueachot, Faculty of Education, Mahasarakham University, Thailand. Tel: \\ 66-871-696-479. E-mail: Staryumutita@hotmail.com
}

\author{
Received: July 7, 2013 Accepted: August 5, $2013 \quad$ Online Published: August 29, 2013 \\ doi:10.5539/ies.v6n9p119 URL: http://dx.doi.org/10.5539/ies.v6n9p119
}

\begin{abstract}
Assessment for Learning for elementary classroom is a concept that aims to stimulate self learning and development among the student via assessment model. This research aimed to 1) develop an Assessment for Learning Model for elementary classroom and 2) test and assess the outcome of our model. The authors utilized interviewing, questionnaire and assessment form as tools for data gathering. The data was analyzed by statistical methods, namely, mean and standard deviation. Lastly, we performed the t-test Dependent to test our hypothesis and we've found that the Assessment for Learning Model for elementary classroom comprises of 2 phase and 6 steps. The result comprises two stages. The planning stage is composed of (1) define assessment objectives and what students need to achieve (2) define performance benchmark (3) design learning methodology and assessment method in accord with learning objectives. The teaching and feedback stage is composed of (1) integrate assessment with teaching/learning activities (2) Feedback after learning unit (3) Feedback result is used to improve primary school student's performance. The result of using the designed assessment model reveals that students have improved their learning achievement, self-regulation, and self-efficacy at statistically significant level of .05.
\end{abstract}

Keyword: assessment for learning, formative assessment, classroom assessment, elementary student, self-efficacy learning, self-regulated learning

\section{Introduction}

National Education Act B.E. 2542 (2nd Revision) aims to simulate student to develop themselves to their utmost potential while places significance focus on learning practice and learning assessment. Janekarn (2007) proposed to change teacher's role from 'Chalk and Talk' to 'the facilitator' of student's learning and focus the student on various practicing activities that stimulate learning and cultivate skills, which will ultimately lead them to achieve the defined national education standard. However, not only the forms of learning that need to be change but also the forms of learning assessment, as they are seamlessly connected. Therefore, now assessment is not only the evaluation whether student pass or fail the subject, assessment should also inform them how much progress they have made in that subject and how could they reach the defined learning standard. Broadfoot (1996) stated that the most vital aspect of any assessment, was the assessment should promote the learning rather than demote it.

Assessment for Learning had changed the principal ideas about classroom assessment and affected the learning management to become something more than just regulating student's learning. More and more evidences from hundreds of researching in this subject around the world in the past decade depict that application of Assessment for Learning could result in a unprecedented progression from student, especially for those who hardly made progress during the past years. The result was also the significance increasing in learning achievement that almost covered the yearly progress goal and significantly increasing the learning achievement score. (Stiggins, 2005) United States of American and many other countries classify the instructional intervention as a black box, which comprises of many opened-vital components, such as, teach, student, learning resources, regulation, management scheme and etc. Parents and involved parties still concern about the standard of external assessment, Black and William (1998) Beside boosting learning achievement, many procedures of the Assessment for Learning - such as defining the goal, self assessment and giving feedback - also help stimulate self-efficacy and self-regulate among student. (Sadler, 1998; Pintrich and Zusho, 2002; Butler and Winne, 1995; Zimmerman \& 
Schunk, 2001) Summarily speaking, the Assessment for Learning is a smart - self regulation technique that let student define the goal they they'll need to work their way to achieve. Such goal must be comparable and applicable as assessment criterion, for assessing their progression toward achieving both school's and external's assessment standard. The revelation of such goal and standard requires student's feedback and opinion relates their learning activities and progression. The feedback can later use to improve the learning management which ultimately will stimulate better learning achievement among the student. The Assessment for Learning also stimulates self-regulated learning which also facilitate the student to reach further learning achievement.

Assessment for Learning is also known as Formative Assessment, however, formative assessment can be truly regard as an Assessment for Learning only when it has been perform continuously, such as on daily basis with significant amount of assessment's frequency and feedback. Formative Assessment is a technique to monitor student's development during the learning session and at the end the learning result will reflect the responsibility (school's performance). The objective of the Assessment for Learning had been focus on promoting the school's overall activities, as it allows the school's operator to recognize their teaching's quality on day-to-day basis. It cans also boosting the level of overall testing score. Assessment for Learning (AFL) means using evidence and feedback to specify what have one learn and what did one need to do next which will guide them through the best way of learning that will ultimately lead them to their learning objective. (Black et al, 2003) The development of learning and desired characteristic in student is a cumulative - ongoing process, hence, teacher, students and every involved parties must understand and capable of designing learning and assessment method that conform with the principle of Assessment for Learning for elementary student. Integrating this concept as a part of the learning management will be a vital part for a sound learning assessment model that can truly further improve overall education quality.

\section{Research Question}

2.1 What Should be the Components of the Assessment for Learning for Elementary Student?

2.2 What is the Overall Resulted Quality of the Assessment for Learning for Elementary Student? Judging from these Desired Results in the Student:

1) Self-efficacy learning

2) Self-regulated learning

3) Achievement

\section{Research Scope}

3.1 Population and Samples

1) Population is $5^{\text {th }}$ grade elementary student, who's studying in their $2^{\text {nd }}$ semester of the academic year 2012 , from Anubal Lerng Nok-ta School, under the supervision of Yasothorn Primary Educational Service Area Office 2. There were 107 students from 3 classrooms.

2) Samples is $5^{\text {th }}$ grade elementary student from Anubal Lerng Nok-ta School, under the supervision of Yasothorn Primary Educational Service Area Office 2. The researchers performed the simple random sampling to pick the student from class 5/3 (37 students) as this research's samples.

3.2 Variables being Study is the Overall Quality of the Assessment for Learning Model for Elementary Student, Namely

1) Student's self-efficacy learning

2) Student's self-regulated learning

3) Student's achievement

\section{Research Hypothesis}

1) For those students who had experience with our Assessment for Learning Model, their learning achievement after the experience should be higher than before the experience.

2) For those students who had experience with our Assessment for Learning Model, their self-efficacy learning after the experience should be higher than before the experience.

3) For those students who had experience with our Assessment for Learning Model, their self-regulated learning after the experience should be higher than before the experience. 


\section{Research Methodology}

We utilized Research and Development methodology in this study, and it comprises of 2 main phases, namely:

Phase 1: Studying of basic principle, concept, theory and general information regarding the Assessment for Learning, then created our version of Assessment for Learning Model. We've studied the application of Assessment for Learning in classroom, collected and analyzed the data about the Assessment for Learning. We use the progression assessment model from The Basic Education Core Curriculum B.E. 2008 as a guideline to define the components and design our Assessment for Learning Model. We've interviewed 10 qualified people in the field of learning evaluation and assessment and used the data to build our Assessment for Learning Model. Lastly, we confirmed the credibility of our model and its components by two groups of specialists, namely: a group of 9 educators and a group of 10 best-teaching teachers.

Phase 2: Trial test of our Assessment for Learning Model, to test out its performance and quality when applied it to elementary class. This is a on-the-job testing in the classroom, to see the probability for its application in the real world. The method for this phase is pre-test and post-test that performed before and after the application of the Assessment for Learning Model. We used some tests to gather information in this phase, namely, learning achievement test, self-efficacy learning test, self-regulated learning test. We also used satisfactory evaluation form and questionnaire to gathered feedback from the student toward our Assessment for Learning Model. Then we evaluated the overall quality of our model from

1) The mean score of student's self-regulated learning

2) The mean score of student's self-efficacy learning

3) Comparing of student's achievement

To test our model, the researchers sampled the learning subject that will be subsequently used with our model, with simple random sampling; we picked Math for $5^{\text {th }}$ grade student, which comprise of 3 units, namely: Chapter 5 Triangle, Chapter 6 Square and Chapter 7 Circle. The test run accumulated to 32 hours, including both pre-test and post-test session. The authors arrange all the learning activities, in according with our developed Learning Intervention Plan.

\section{Data Analysis}

The authors brought together the result from learning achievement test, self-efficacy learning test, self-regulated learning test. The tests inspected and assigned with scores, which later were used to calculate the statistical data. This statistical data then compare between before and after the application of our Assessment for Learning Model, using t-test Independent, the results are as follow:

Table 1. Comparing the results of learning achievement test, self-efficacy learning test, self-regulated learning test; between before and after the application of the Assessment for Learning Model with elementary class

\begin{tabular}{llllll}
\hline Variable & Test result & $(\mathrm{X})$ & S.D. & $\mathrm{t}$ & $\mathrm{P}$ \\
\hline Learning & Pre-test & 15.76 & 1.67 & $27.290^{*}$ & 0.00 \\
Achievement & Post-test & 25.00 & 1.27 & & \\
& & & & & \\
Self-efficacy & Pre-test & 21.62 & 1.41 & $22.556^{*}$ & 0.00 \\
Learning & Post-test & 27.65 & .86 & & \\
Self-regulated & Pre-test & 29.23 & .81 & & \\
Learning & Post-test & 37.64 & 1.11 & $32.476^{*}$ & 0.00 \\
\hline
\end{tabular}

The scores on learning achievement, self-efficacy and self-regulation are higher after the experiment at a statistically significant level of .05 . 


\section{Conclusion and Discussion}

7.1 The Study Conclusion is That Assessment for Learning for Primary School Students Can be Divided into 2 Stages, Each with 3 Steps, Altogether 6 Steps

1) The planning stage is composed of (1) define assessment objectives and what students need to achieve (2) define performance benchmark (3) design learning methodology and assessment method in accord with learning objectives.

2) The teaching and feedback stage is composed of (1) integrate assessment with learning activities (2) Feedback after learning unit (3) Feedback result is used to improve student's performance.

That the study yields this result may be due to the fact that the researcher has undertaken this research in a systematic manner, ranging from literature review, reading up on research papers on student's assessment, and interviewing experts who have extensive experiences in classroom assessment. All these inputs are synthesized to come up with an assessment method that is appropriate to use in the targeted classroom. This includes integration of assessment into learning activities that students can set their own learning goals and develop themselves to achieve learning objectives, stressing self-competition to reach prescribed goals of being happy, capable and virtuous in accord with section 6 of National Education Act B.E. 2551, 2nd Revision (Office of National Education, 2003). This result is also in accord with Wiggins (1989) which noted that assessment is to evaluate achievement using knowledge and reasons at a higher level than just determining the correct/incorrect answer from the student. Therefore, students can generate learning from working on valuable things that are beneficial to the learners and that they must know what is accepted good practice by using assessment feedback to develop themselves and discover their own ways of self-learning. Furthermore, the designed Assessment for Learning method is based on reliable past researches and verified by experts in the field as well as by primary school teachers. It also follows Navarrete \& Gustke (1996) that good assessment must integrate students' learning activities, stressing practice on what students need to learn and that a variety of assessment tools are clearly defined. Bookhart (2006) noted that assessment involved cooperative workings between teachers and students, giving emphasis to learning objectives, work accumulation in line with goals, and working toward goals. Assessment Reform Group (1999) noted that assessment is part of teaching and learning processes and that assessment can bring open what has previously been hidden and that students will gain skills from assessment to learn further. This is affirmed by Shute (2008) that assessment feedback to students is aimed at students adjusting their learning behaviors. Students may not follow all the feedback recommendations but they certainly do adjust learning. Emily (2010) found out that the most effective feedback on student's learning generates self-modification to improve while only positive feedback may not promote all aspects of learning.

\subsection{Quality of Assessment for Learning for Primary School Students Yielded}

1) Comparing learning achievement before and after the experiment, it was found that learning achievement was significantly higher at .05 level. This is mainly due to students having done real practice which is in accord with Assessment for Learning principle backed up by more than 100 researches over the last 10 years. The progress achievement is unprecedented especially among those low-level achievers previously (Stiggins, 2005) and in accord with Wiggins (2005) that assessment for learning that employs knowledge, reasons and high-level thinking should be the aim rather than to want to know whether a student's answer is correct or incorrect. Teacher must facilitate student's learning, self-learning and discovery. Before students start learning, they must be informed about the lesson's objectives to provide incentive and learning guideline, and that assessment must provide learning feedback to help students develop, self-discover learning their own ways.

2) Comparing self-efficacy before and after the experiment, it was found that self-efficacy was significantly higher at .05 level. It is found that students have the chance to develop themselves continuously, to participate in assessment including determining assessment criteria and recording assessment result in student's record book. All these activities help students learn their own strengths and weaknesses and the feedback provides students with self-development guideline. Students learn through practice and interaction among students and with teacher. This stimulates self-development as students are in the same age group, thus they are not afraid to speak out, and can accept peer's appraisal. The designed assessment method is also flexible enough to enable students to participate in determining evaluation criteria as well as having a chance to assess himself as well as peer. All these enable the experiment group students to have higher self-efficacy than the control group. Bandura (1986) noted that if one were to know a person's self-efficacy, one could predict that person's behavior under ambiguous situation. Bandura (1994) also observed that a learner would choose to do what he thinks he can do and would try to avoid taking action that is deemed beyond his capability. Applying this to classroom students, a learner with high self-efficacy would choose to undertake a challenging task while a learner with low self-efficacy 
would be discouraged and try to avoid any hard task, closing himself to self-development. Therefore, in organizing learning activities, a student must be provided with an opportunity to choose a learning task that is appropriate to his competency level to achieve learning objectives.

3) Comparing self-regulation before and after the experiment, it was found that self-regulation was significantly higher at .05 level. When compared with the control group after the experiment ended, it was found that the experiment group's self-regulation and learning achievement was higher at .05 significant level. This may be due to the fact that the experiment group provides activities that let students set their own learning goals, assessment criteria, and the assessment feedback is recorded on student's book. The assessment method is also flexible that can be applied in many learning situations so that students can achieve learning goals by themselves. The method provides practice for students to know how to set their own goals, how to apply themselves to reach their goals. Students are allowed to help set the assessment method, monitor and assess themselves regularly as well as their peer. They have a chance to solve problems and learn from regular feedback. It can be said that the experiment primary school students receive valuable experiences in self-learning and self-regulation to achieve learning objectives. Students that have set learning goals and engaged in self-appraisal would exhibit higher self-regulation than students without. Assessment for Learning also provides students an opportunity to express themselves, interact with their peer and teacher, thus enable students to accumulate all these experiences to refine their learning strategies and improve their learning capability, which is in accord with Zimmerman (1989) who noted that the most important factor in self-regulated learning is content knowledge and self-regulation knowhow, knowing his own thought process and learning objectives. The present research result is also in accord with Khamnadee (2008) study that students provided with self-regulated learning environment scored higher on mathematics than a control group at .05 level.

\section{References}

Assessment Reform Group. (1999). Assessment for Learning: Beyond the Black Box. University of Cambridge, Faculty of Education.

Bandura, A. (1986). Social Foundations of Thought and Action: A Social Cognitive Theory. New Jersey: Prentice - Hall.

Bandura, A. (1994). Self-efficacy. In V. S. Ramachandran (Ed.), Encyclopedia of Human Behavior. New York: Academic Press, 1994.

Black, P., \& Wiliam, D. (1998). Assessment and Classroom Learning. Assessment in Education, 5(1). London: School of Education King's College.

Black, P., Harrison Ch., Lee C., Marshall B., \& Wiliam D. (2003). Assessment for Learning: Putting It in to Practice. Maidenhead: Open University Press.

Broadfoot, P. M. (1996). Education, Assessment and Society. Buckingham, England: Open University Press.

Brookhart, S. (2006). Formative Assessment Strategies for Every Classroom. Alexandria, VA: ASCD.

Butler, D. L., \& Winne, P. H. (1995). Feedback and Self-regulated Learning: A Theoretical Synthesis. Review of Educational Research, 65(3), 245-281. http://dx.doi.org/10.3102/00346543065003245

Emily S. M. (2010). Student Use of Formative Assessment and Formative Assessment in the 7th Grade Science Class. A Professional Paper Submitted in Partial Fulfillment of the Requirements for the Degree. Montana State University. p 46.

Janekarn, T. (2007). Assessment for Learning, translated and adapted from Assessment for Learning, Rick Stiggins: 2005 and Georgia Department of Education: 2000 Bangkok: Learning Intervention and Learning Assessment Working Group, Ministry of Education.

Kumnadee, S. (2008). Researching and developing Self-Regulated Learning for learning management in Math to improve self-efficacy learning, attitude, and learning achievement in $2^{\text {nd }}$ grade elementary student. Thesis, Science of Education Bangkok: Chulalongkorn University.

Navarrete, C. J., \& Gustke, C. (1996). A Guide to Performance Assessment for Linguistically Diverse Students. Albuquerque, NM: Evaluation Assistance Center-West. p10-13.

Office of National Education. (2003). Report on National Pilot Project on Learning Quality Development: Assessment and Assurance, Bangkok. 
Pintrich, P. R., \& Zusho, A. (2002). "Student Motivation and Self - regulated Learning in the College Classroom. In J. C. Smart, \& W. G. Tierney (Eds.), Higher Education: Handbook of Theory and Research (Volume 17), New York, Agathon Press. http://dx.doi.org/10.1007/978-94-010-0245-5_2

Sadler, D. R. (1998). Formative Assessment and the Design of Instructional Systems. Instructional Science, $18(4)$.

Shute, V. (2008). Focus on Formative Feedback. Review of Educational Research, 78(1), $153-189$. http://dx.doi.org/10.3102/0034654307313795

Stiggins R. (2005). From Formative Assessment to Assessment for Learning: A Path to Success In Standards based Schools. Phi Delta Kappan, 87(4), 2005.

Wiggins, G, J. (2005). Understanding by Design. Alexandria, VA: Association for Supervision and Curriculum Development.

Winggins, G. J. (1989). The Futility of Trying to Teach Everything of Importance. Educational Leadership, 46(3), 44-59.

Zimmerman, B. J., \& Schunk, D. H. (2001). Self-regulated Learning and Academic Achievement: Theoretical Perspectives (Lawrence Erlbaum Associates, New Jersey).

Zimmerman, Barry J. (1989). A Social Cognitive View of Self - regulated Academic Learning. Journal of Educational Psychology, 81(3), 329-339. http://dx.doi.org/10.1037/0022-0663.81.3.329

\section{Copyrights}

Copyright for this article is retained by the author(s), with first publication rights granted to the journal.

This is an open-access article distributed under the terms and conditions of the Creative Commons Attribution license (http://creativecommons.org/licenses/by/3.0/). 